\title{
Molecular confirmation of two medicinal species of Jatropha L. (Euphorbiaceae) used by the Agusan Manobo in the Philippines
}

\author{
Kathleen Marie B. Tan ${ }^{1}$, Maria Francesca D. Tuazon ${ }^{1}$, Isabelle Beatriz F. Pagkalinawan ${ }^{1}$, \\ Mark Lloyd G. Dapar ${ }^{* 4,5}$, E Grecebio Jonathan D. Alejandro ${ }^{1-3}$ \\ ${ }^{1}$ College of Science; ${ }^{2}$ The Graduate School; ${ }^{3}$ Research Center for the Natural and Applied Sciences, \\ University of Santo Tomas, España Boulevard, 1015 Manila, Philippines \\ ${ }^{4}$ Department of Biology; ${ }^{5}$ Center for Biodiversity Research and Extension in Mindanao, Central \\ Mindanao University, University Town, Musuan, Bukidnon 8710, Philippines
}

\begin{abstract}
The Agusan Manobo in the Philippines is known to use complex plant vernacular names. One of their interesting medicinal plants having local name similarity is called "tubatuba" in Bisayan and Minanubu dialects. The local name refers these plants to two different specimens; one is "tubatuba puti," and the other is "tubatuba tapol," which are classified by the tribe based on their distinct color shades of white and red, respectively. This study verifies the true identity of the two "tubatuba"-named specimens using molecular data and morphology. Molecular confirmation using BLASTn nucleotide database query revealed that the two confused samples are members of Euphorbiaceae and its verified generic affinity is Jatropha L. Phylogeny of 24 Jatropha specimens using ITS sequences revealed "tubatuba puti" as Jatropha curcas L. and "tubatuba tapol" as Jatropha gossypiifolia L. with strong Bootstrap support ( $\mathrm{BS}=100 \%)$. Morphological descriptions and field photographs of the two Jatropha species, as well as their conservation status based on the international and national red listings, are provided here.
\end{abstract}

Keywords: Agusan Manobo, BLASTn, Euphorbiaceae, ITS, Jatropha species, molecular confirmation

\section{INTRODUCTION}

Jatropha L. of the family Euphorbiaceae is composed of 175 species diversified across the subtropical and tropical regions of the world [1, 2]. Classified into two subgenera: Jatropha is found in South America, Antillean Islands, Africa, and India, while Curcas inhabits the lands

*To whom correspondence should be addressed: marklloyd.dapar.gs@ust.edu.ph of North America and Mexico [2, 3]. Currently, there are five Jatropha species (J. curcas L., J. gossypiifolia L., J. integerrima Jacq., $J$. multifida L., and J. podagrica Hook.) known to be present in the Philippines [4].

Based on the folk medicine of Jatropha species in the Philippines, two species, namely J. curcas and J. gossypiifolia, are widely used as medicine. Dapar et al. [5] documented the ethnopharmacological use of these two 
medicinal plants among the Agusan Manobo as a treatment for both internal and external conditions. Drinking decoctions of leaves and roots can alleviate colds, malaria, typhoid fever, pulmonary tuberculosis, diarrhea, arthritis, rheumatism, dysmenorrhea, irregular menstruation, backache, body ache, fever, weakness, fatigue, cramp, spasm, relapse, gas pain, and flatulence [5]. Also, applying decocted roots and pounded scraped barks are effective against scabies, ringworm, ear infection, discharging ear, toothache, mouth sore, cuts and wounds, fracture, dislocation, and bites (animal and insects). This plant can also be used as a bath or wash using decocted leaves in treatment for ringworm, boils, carbuncles, dermatitis, swollen muscles, swellings, muscle pain, backache, body ache, fever, cuts, and wounds [5]. Decocted leaves of these two species were recently reported by Dapar et al. [6] among Agusan Manobo to wash on burns, injuries, cuts, and wounds. Other ethnobotanical accounts mentioned that both $J$. curcas and $J$. gossypiifolia are used in treatments to cure arthritis, body pain, fatigue, tuberculosis, diarrhea, menstrual problems, and related spasms $[7,8]$.

Folklorically, both J. curcas and J. gossypiifolia are referred to as the local name "tubatuba". Based on the ethnoclassification of Agusan Manobo, each plant is distinguished based on its coloration. Accordingly, the one having shades of white is known as "tubatuba puti," while for red is known as "tubatuba tapol," with the latter being more effective than the former. However, the ethnoclassification of Agusan Manobo poses the complexity of the correct species identity based on color differences. Dapar et al. [9] deduced the importance of integrating molecular data and morphology of plants to evaluate traditional limits of identification. Although the main distinction is in the color of the vegetative parts, molecular data are needed to examine further the true familial and generic affinities as well as the phylogenetic placement of the species. Thus, this study aims to (1) confirm the familial and generic affiliations, and (2) resolve phylogenetic placements of the two "tubatuba"-named specimens used by the Agusan Manobo of Agusan del Sur, Philippines.

\section{MATERIALS AND METHODS}

All necessary ethics approval, permit, certification, and fee prior informed consents were secured before fieldwork and plant collection. The collection of the plant samples was then followed through guided field walks with tribal healers who are knowledgeable of their "tubatuba"-named medicinal plants. A plant sample classified as "tubatuba puti" and one "tubatuba tapol" (Fig. 1) was collected in Bayugan City, Agusan del Sur. Voucher specimens were deposited in the University of Santo Tomas Herbarium (USTH) with accession numbers, as presented in Table 1.

The total genomic DNA was extracted from silica gel-dried leaf tissues of "tubatuba puti" and "tubatuba tapol" samples following the protocols of DNeasy Plant Minikit (Qiagen, Germany). The internal transcribed spacer (ITS) of nuclear DNA (nrDNA) marker was amplified and sequenced using the primer pairs, P17F and 26S-82R. PCR reactions were administered on a Biometra T- Gradient with a total volume of $25 \mathrm{~L}$ following the PCR parameters and mixture of Alejandro et al. [10]. Amplified DNA was purified using QiaQuick PCR Purification Kit (Qiagen, Germany) before sending it to MACROGEN Inc., Seoul Korea, for bidirectional sequencing.

The sequences of studied samples were assembled and edited using Codon Code Aligner v8.0.2, trimmed, and checked for ambiguous nucleotides. A BLASTn search was performed to check for species identity using the BLASTn algorithm available in the GenBank (www.ncbi.nim.nih.gov), as shown in Table 1. Available sequences of all reported Philippine 


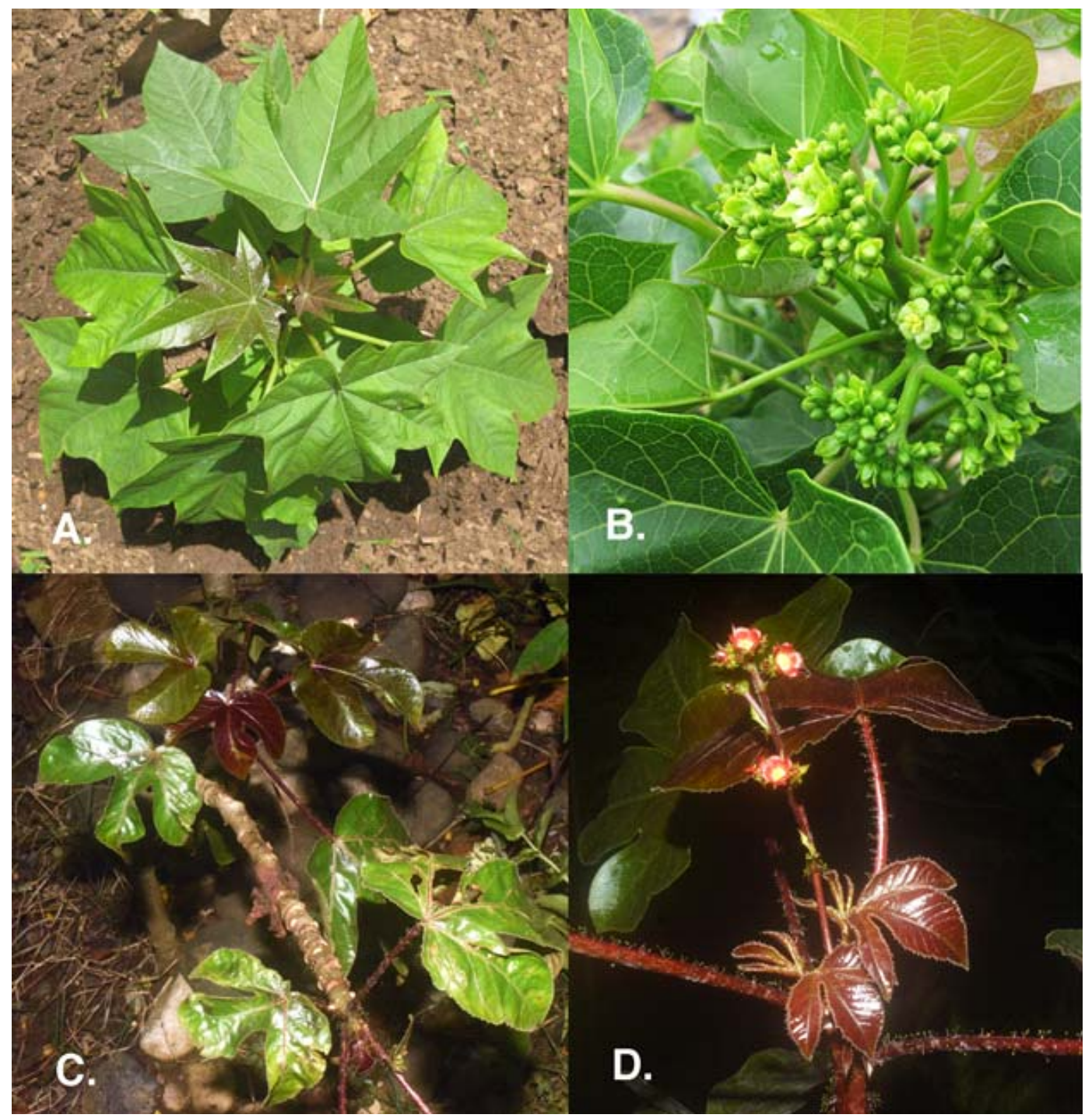

Figure 1. Field photographs of "tubatuba"-named specimens: (A) "tubatuba puti" (Jatropha curcas L.) leaves, (B) inflorescence, (C) "tubatuba tapol” (Jatropha gossypiifolia L.) leaves, and (D) inflorescence. Photos taken by M.LG. Dapar.

Table 1. BLASTn results of newly sequenced samples based on the ITS marker.

\begin{tabular}{c|c|c|c|c}
\hline \multirow{2}{*}{ Local name } & \multirow{2}{*}{ Sample code / Voucher } & \multicolumn{3}{|c}{ (nrDNA) ITS } \\
\cline { 3 - 5 } & & BLAST ID & e-value & $\%$ identity \\
\hline "tubatuba puti" & 19MD-019/ USTH015595 & Jatropha curcas & 0.0 & $100 \%$ \\
\hline "tubatuba tapol" & 19MD-129/ USTH015621 & Jatropha gossypiifolia & 0.0 & $100 \%$ \\
\hline
\end{tabular}


Table 2. Nucleotide sequence database accession numbers of taxa used in the ITS phylogenetic analysis.

\begin{tabular}{|c|c|c|c|}
\hline \multirow{2}{*}{ Species } & \multirow{2}{*}{ Genbank accession code } & \multicolumn{2}{|c|}{ (nrDNA) ITS } \\
\hline & & $e$-value & \% identity \\
\hline \multicolumn{4}{|l|}{ Outgroup } \\
\hline Croton draco Schltdl. & EU478006.1 & 0 & $100 \%$ \\
\hline \multicolumn{4}{|l|}{ Ingroup } \\
\hline \multirow{20}{*}{ Jatropha curcas L. } & KP190942.1 & 0 & $100 \%$ \\
\hline & KP190943.1 & 0 & $100 \%$ \\
\hline & KP190956.1 & 0 & $100 \%$ \\
\hline & KP190957.1 & 0 & $100 \%$ \\
\hline & KP190959.1 & 0 & $100 \%$ \\
\hline & KP190961.1 & 0 & $100 \%$ \\
\hline & KP191042.1 & 0 & $100 \%$ \\
\hline & KP190971.1 & 0 & $100 \%$ \\
\hline & KP190976.1 & 0 & $100 \%$ \\
\hline & KP190982.1 & 0 & $100 \%$ \\
\hline & KP190989.1 & 0 & $100 \%$ \\
\hline & KP190997.1 & 0 & $100 \%$ \\
\hline & KP190998.1 & 0 & $100 \%$ \\
\hline & KP191024.1 & 0 & $100 \%$ \\
\hline & KP191029.1 & 0 & $100 \%$ \\
\hline & KP191031.1 & 0 & $100 \%$ \\
\hline & KP191033.1 & 0 & $100 \%$ \\
\hline & KP191034.1 & 0 & $100 \%$ \\
\hline & KP191035.1 & 0 & $100 \%$ \\
\hline & KP191036.1 & 0 & $100 \%$ \\
\hline \multirow{4}{*}{ Jatropha gossypiifolia L. } & KP191041.1 & 0 & $99.83 \%$ \\
\hline & EU340792.2 & 0 & $100 \%$ \\
\hline & EU340793.2 & 0 & $80.35 \%$ \\
\hline & KF500510.1 & 0 & $100 \%$ \\
\hline \multirow{2}{*}{ Jatropha integerrima Jacq. } & EU340795.2 & 0 & $99.83 \%$ \\
\hline & MN688731.1 & 0 & $92.02 \%$ \\
\hline \multirow{2}{*}{ Jatropha multifida L. } & EU340789.2 & 0 & $97.95 \%$ \\
\hline & EF599630.2 & 0 & $98.12 \%$ \\
\hline \multirow{2}{*}{ Jatropha podagrica Hook. } & KP868740.1 & 0 & $99.12 \%$ \\
\hline & KF500509.1 & 0 & $99.83 \%$ \\
\hline
\end{tabular}

Jatropha species [4], including from the study of Guo et al. [11] of key Jatropha species, were included in the analysis. A total of 30 accessions of Jatropha species and an outgroup (Croton draco Schltdl.) were included in a parsimony analysis of the ITS marker (Table 2).

Before the final visual inspection, several alignments of sequences were conducted in MEGAv.7.0.18 [12] using the MUSCLE alignment [13]. Bootstrap replicates of 1000 were utilized to run and perform parsimony analysis using the TBR search method with 100 random incorporations of initial trees. Homoplasy was approximated by quantifying the consistency index (CI) [14] and retention index (RI) [15].

\section{RESULTS AND DISCUSSION}

Nucleotide analysis. The BLASTn results of successfully sequenced ITS of the two "tubatuba"-named specimens identified these 
as members of the genus Jatropha (Euphorbiaceae) with e-values $=0$ and identities of $100 \%$ (Table 1$)$.

Molecular confirmation. In verifying the species identity of medicinal plants with similar local names or uncertain species identity, the use of molecular sequences has become a powerful tool [11]. The two "tubatuba" voucher specimens were verified as $J$. curcas for "tubatuba puti" and J. gossypiifolia for "tubatuba tapol" based on the ITS marker. As a universal marker, ITS renders high interspecific divergence and greater discriminatory power over plastid regions $[16,17]$. In general, it is utilized for species-level phylogenetic studies between plants and fungi that are associated with the recently diverged taxa [18]. Furthermore, due to its small size, it can be easily amplified with a universal marker designed by White et

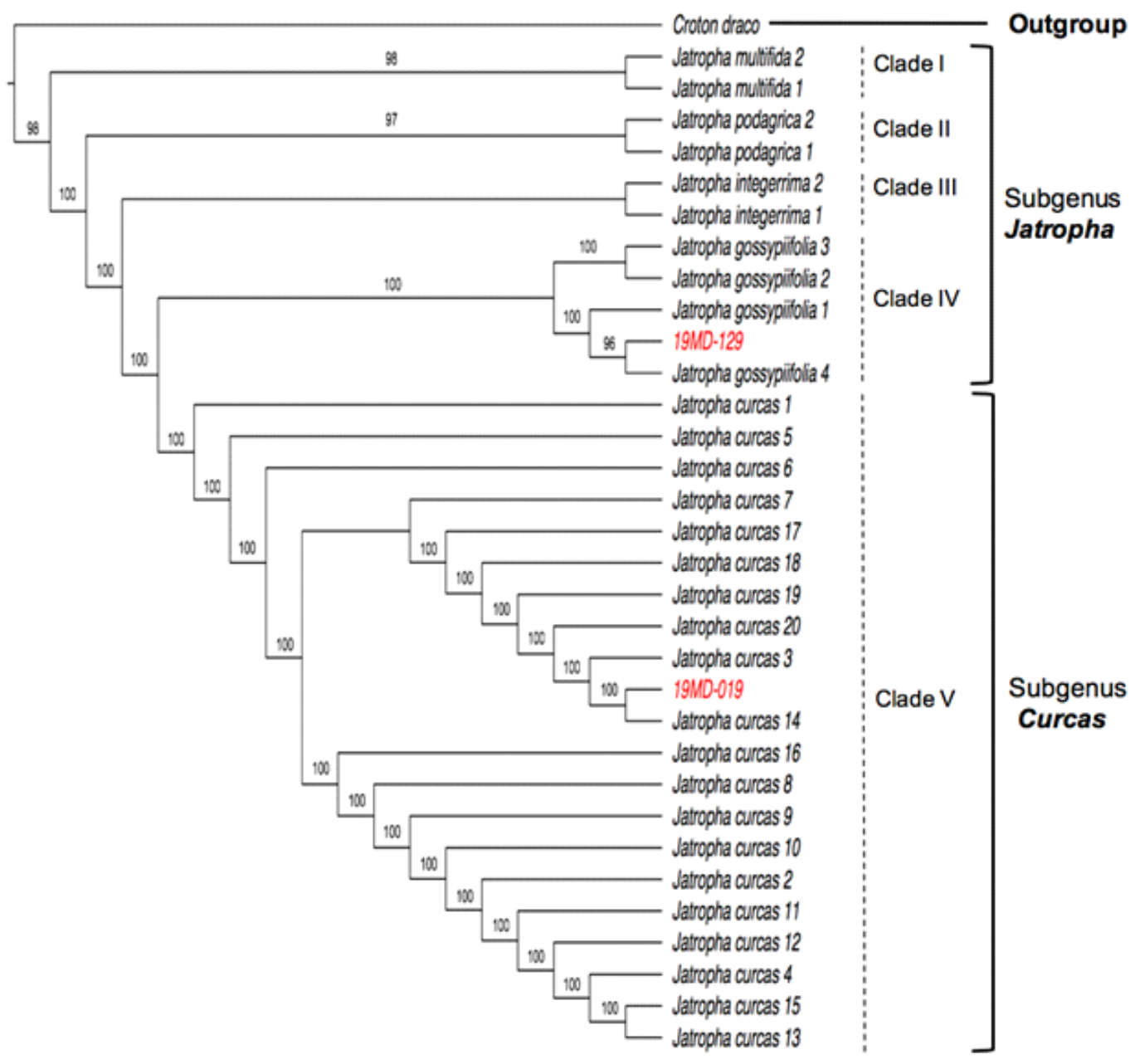

2.0

Figure 2. Strict consensus tree derived from eight equally parsimonious trees based on the phylogenetic analysis of ITS sequence data. Length $=438$ steps; Consistency index $=0.83$; Retention index $=0.82$. Branch lengths are drawn to scale. Percentage of 1000 bootstrap replicates is given when higher than $50 \%$. Taxa in red emphasize where the newly included samples (19MD-129 and 19MD-019) are nested. 
al. [19] and is taken into account as a supplementary locus for plant barcode [17].

Specimens that were amplified using the ITS marker resulted in a $100 \%$ success rate. They were identified down to their species level by simple BLAST-search query. The molecular confirmation verified the morphological identities examined.

Phylogenetic analysis. The obtained maximum parsimonious tree (Fig. 2) is governed by a bisection between two subgenera classifications, namely Jatropha and Curcas. The first section of the phylogenetic tree shows the representative members of the subgenus Jatropha, composed of J. multifida, J. podagrica, J. integerrima, and J. gossypiifolia. This subgenus, however, is subdivided into different lineages (I, II, III, and IV) per species. Although all species of subgenus Jatropha are known to be naturalized in the Philippines, the observed interspecific relation between them implies that these obtained specimens belong to different countries of origin [4].

As for the subgenus Curcas, all J. curcas specimens were grouped in Clade $\mathrm{V}$, wherein the majority, including the collected sample, was branched from one same lineage. The other three J. curcas (labeled as 1, 5, and 6) separated from the majority of $J$. curcas, which suggests that these were the probable cause of varied geographical and environmental conditions [11]. As opposed to the obtained accessions from Myanmar, other parts of China, India, Mali, Burkina Faso, and Philippine tropics, these three divergent $J$. curcas (labeled 1,5 and 6) share their origins from the arid-upland climate of Southwestern China [20].

Both J. gossypiifolia and J. curcas voucher specimens are nested together with their corresponding accession counterparts from India, in clades I and V, respectively. These intraspecific relationships are mainly because of the similar tropical climate conditions they were propagated from [3].

Comparative morphology of J. curcas and $J$. gossypiifolia. This section contains the general vegetative and reproductive morphology along with the distribution, habitat, and conservation status of J. curcas and J. gossypiifolia. A comparative summary of the two Jatropha species is presented in Table 3.

Jatropha curcas is an upright shrub or small tree that grows ca. 2-4 m tall. Stem woody brown, $1.5-2 \mathrm{~cm}$ thick, exudes watery sap when broken. Pedicel 3-7 cm long with racemose inflorescence. Leaves glabrous, divided into 35 palmately lobed. Leaf blades round to ovate, $10-19 \mathrm{~cm} \times 5-15 \mathrm{~cm}$, acute at apex, cordate at base, glabrous on the upper surface, 7-10 lateral nerve pairs. Flowers small, yellow to green. Fruits oval, 3-4 cm, crowned by calyx lobes. Calyx ovate, $0.4 \mathrm{~cm}$ long; lobes $2-4,3.2-5 \mathrm{~cm}$ long. Corolla green, ovate, $3-5 \mathrm{~mm}$ in length; anther unequal. Style $2-5.6 \mathrm{~mm}$ long, connate at $2 / 3$ of its length [21].

Jatropha gossypiifolia is an upright shrub or small tree that usually grows ca. $1-3 \mathrm{~m}$ tall. Stem woody green, $1-3 \mathrm{~cm}$ thick, and exude a soapy sap when broken. Pedicel 2-10 cm long, inflorescence racemose. Leaves are alternately arranged, with 3 or 5 pointed lobes, and dark reddish-purple when young. Leaf blades 4.5-10 $\mathrm{cm} \times 5-13 \mathrm{~cm}$, palmately lobed to partite with lobed segments and palmate venation, acute to acuminate at apex, shallow at base, glabrous on the upper surface, 7-11 lateral nerves pairs. Flowers small, glabrous, deep red with yellow centers, obovate, $3-5 \mathrm{~mm}$ long. Flowers are borne in clusters in the upper leaf forks. Calyx ovate to lanceolate, $0.7 \mathrm{~cm}$ long; lobes $3-5$ lobes, $3 \mathrm{~cm}$ long. Capsules 3-lobbed seeds, fleshy, usually bright, glossy green, sometimes sparsely hairy. Fruits crowned by calyx lobes, oblong, 1.2-1.3 $\mathrm{cm}$ long. Style $1 \mathrm{~mm}$, anther unequal length [22]. 
Table 3. Comparative morphology of J. curcas and J. gossypiifolia.

\begin{tabular}{|c|c|c|}
\hline & Jatropha curcas & Jatropha gossypiifolia \\
\hline Habit & Shrub & Shrub \\
\hline Height & $2-4 \mathrm{~m}$ & $1-3 m$ \\
\hline \multicolumn{3}{|l|}{ Stem } \\
\hline Thickness & $1.5-2 \mathrm{~cm}$ & $1-3 \mathrm{~cm}$ \\
\hline Structure \& Color & Woody covered in brown & Woody covered in green \\
\hline \multicolumn{3}{|l|}{ Petiole } \\
\hline Length & $6-18 \mathrm{~cm}$ & $7-12 \mathrm{~cm}$ \\
\hline \multicolumn{3}{|l|}{ Leaf Blade } \\
\hline Shape & Round to ovate & $\begin{array}{l}\text { Palmately lobed to partite with lobbed } \\
\text { segments }\end{array}$ \\
\hline Venation & Pinnate/palmate & Palmate \\
\hline Length & $10-19 \mathrm{~cm}$ & $4.5-10 \mathrm{~cm}$ \\
\hline Width & $5-15 \mathrm{~cm}$ & $5-13 \mathrm{~cm}$ \\
\hline Apex & Acute & Acute to acuminate \\
\hline Base & Cordate & Shallowly \\
\hline Surface & Glabrous on upper surface & Glabrous on upper surface \\
\hline Lateral nerve pairs & $7-10$ pairs & $7-11$ pairs \\
\hline \multicolumn{3}{|l|}{ Inflorescence } \\
\hline Type & Racemose & Racemose \\
\hline \multicolumn{3}{|l|}{ Pedicel } \\
\hline Length & $3-7 \mathrm{~cm}$ & $2-10 \mathrm{~cm}$ \\
\hline \multicolumn{3}{|l|}{ Calyx } \\
\hline Shape & Ovate & Ovate to lanceolate \\
\hline Length & $0.4 \mathrm{~cm}$ & $0.7 \mathrm{~cm}$ \\
\hline Lobes number & $2-4$ & $3-5$ \\
\hline Lobes length & $3.2-5 \mathrm{~cm}$ & $3 \mathrm{~cm}$ \\
\hline \multicolumn{3}{|l|}{ Corolla } \\
\hline Color & Green & Deep red \\
\hline Shape & Ovate & Obovate \\
\hline Length & $3-5 \mathrm{~mm}$ & $3-5 \mathrm{~mm}$ \\
\hline Surface & Glabrous adaxially & Glabrous adaxially \\
\hline \multicolumn{3}{|l|}{ Anther } \\
\hline Size & Unequal length & Unequal length \\
\hline \multicolumn{3}{|l|}{ Style } \\
\hline Length & $\begin{array}{l}2-5.6 \mathrm{~mm} \text {, connate to about two-thirds } \\
\text { of its length }\end{array}$ & $1 \mathrm{~mm}$ \\
\hline \multicolumn{3}{|l|}{ Fruits } \\
\hline Calyx lobes & Persistent & Persistent \\
\hline Shape & Long-ovoid & Oblong \\
\hline Length & $3-4 \mathrm{~cm}$ & $1.2-1.3 \mathrm{~cm}$ \\
\hline
\end{tabular}

Distribution and habitat. Jatropha curcas was first introduced in the early colonial times from Mexico, then distributed to the tropical regions of Thailand, Sumatra, Peninsular Malaysia, Java, Borneo, Philippines, Sulawesi, Lesser Sunda Islands, Isles of Moluccas, and New Guinea.
This plant is commonly found in hedges throughout the Philippines. On the other hand, J. gossypiifolia is endemic to Mexico to South America and the Caribbean and naturalized throughout the Malesia region, including the Philippines [4]. 


\section{Conservation status. As per IUCN [23], J. curcas} is categorized as endangered, while $J$. gossypiifolia as least concern. However, based on CDFP [4], both Jatropha species in the Philippines have not been evaluated.

\section{CONCLUSION}

Molecular sequences inferred from the nuclear ITS with comparative morphology confirmed the identity of "tubatuba puti" as J. curcas while "tubatuba tapol" as J. gossypiifolia. This study reinforced the ethnoclassification of Jatropha species as different species and supported the application of molecular data for confirmation of uncertain plant species identity.

\section{ACKNOWLeDgments}

We gratefully acknowledge the Agusan Manobo community in Bayugan City and UST-RCNAS for the laboratory facility. GJDA acknowledges the Department of Health - Philippine Institute of Traditional and Alternative Health Care (DOHPITAHC) for the funding.

\section{REFERENCES}

[1] Dehgan B \& Webster GL. Morphology and Infrageneric Relationships of the Genus Jatropha (Euphorbiaceae), Vol. 74. (University of California Press, 1979).

[2] Dehgan B. Phylogenetic Significance of Interspecific Hybridization in Jatropha (Euphorbiaceae). Systematic Botany 1984; 9, 467-478.

[3] Heller J. Physic Nut. Jatropha curcas L. Promoting the conservation and use of underutilized and neglected crops (Ph.D. Thesis). (Rome: Institute of Plant Genetic and Crop Plant Research, Gatersleben, and International Plant Genetic Resource Institute, 1996).

[4] Pelser PB, Barcelona JF, \& Nickrent DL (Eds.). Co's Digital Flora of the Philippines. 2011 onwards. www. philippineplants.org (2020 January 24)
[5] Dapar MLG, Alejandro GJD, Meve U, \& LiedeSchuman S. Quantitative Ethnopharmacological Documentation and Molecular Confirmation of Medicinal Plants Used by the Manobo Tribe of Agusan del Sur, Philippines. Journal of Ethnobiology and Ethnomedicine 2020; 16, 160.

[6] Dapar MLG, Meve U, Liede-Schumann S, \& Alejandro GJD. Ethnomedicinal Plants Used for the Treatment of Cuts and Wounds by the Agusan Manobo of Sibagat, Agusan del Sur, Philippines. Ethnobotany Research and Applications 2020; 19, 1-18.

[7] Chopda MZ \& Mahajan RT. Wound Healing Plants of Jalgaon District of Maharashtra State, India. Ethnobotanical Leaflets 2009; $1,1$.

[8] Kosalge SB \& Fursule RA. Investigation of Ethnomedicinal Claims of Some Plants Used by Tribals of Satpuda Hills in India. Journal of Ethnopharmacology 2009; 121(3), 456-461.

[9] Dapar MLG, Demayo CG, Meve U, Liede-Schuman S, \& Alejandro GJD. Molecular Confirmation, Constituents and Cytotoxicity Evaluation of Two Medicinal Piper species Used by the Manobo tribe of Agusan del Sur, Philippines. Phytochemistry Letters 2020; 36, 24-31.

[10] Alejandro GD, Razafimandimbison SG, \& Liede Schumann S. Polyphyly of Mussaenda Inferred from ITS and trnL $F$ data and Its Implication for Generic Limits in Mussaendeae (Rubiaceae). American Journal of Botany 2005; 92(3), 544557.

[11] Guo G, Wang S, Xu Y, Tang L, Yu M, \& Chen F. Molecular Phylogenetic Analysis of Key Jatropha Species Inferred from nrDNA ITS and Chloroplast (trnL-F and $r b c L$ ) sequences. Genes \& Genomics 2016; 38(6), 557-566.

[12] Kumar P, Gupta VK, Misra AK, Modi DR, \& Pandey BK. Potential of Molecular Markers in Plant Biotechnology. Plant Omics 2009; 2(4), $141-$ 62.

[13] Edgar RC. MUSCLE: Multiple SequenceAlignment with High Accuracy and High Throughput. Nucleic Acids Research 2004; 32(5), 17921797.

[14] Kluge AG \& Farris JS. Quantitative Phyletics and the Evolution of Anurans. Systematic Biology 1969; 18(1), 1-32.

[15] Farris JS. The Retention Index and the Rescaled Consistency Index. Cladistics 1989; 5(4), $417-$ 419. 
[16] Hollingsworth P. Refining the DNA Barcode for Plants. Proceedings of the National Academy of Sciences 2011; 108(49), 19451-19452.

[17] Li X, Yang Y, Henry RJ, Rossetto M, Wang Y, \& Chen S. Plant DNA Barcoding: from Gene to Genome. Biological Reviews 2014; 90(1), 157166.

[18] Kress WJ, Wurdack KJ, Zimmer EA, Weigt LA, \& Janzen DH. Use of DNA barcodes to Identify Flowering Plants. Proceedings of the National Academy of Sciences 2005; 102(23), 8369-8374.

[19] White TJ, Bruns T, Lee S, \& Taylor J. Amplification and Sequencing of Fungal Ribosomal RNA Genes for Phylogenetics. In: Innis M, Gelfand D, Sninsky J, \& White T. (Eds.) PCR Protocols: A Guide to Methods and Applications, p. 315-322. (San Diego: Academic Press, 1990).
[20] Ye M, Li C, Francis G, \& Makkar HP. Current Situation and Prospects of Jatropha curcas as a Multipurpose Tree in China. Agroforestry Systems 2009; 76, 487-497.

[21] Environmental Weeds of Australia for Biosecurity Queensland. Jatropha curcas L. 2016. https:// keyserver.lucidcentral.org/weeds/data/media/ Html/jatrophacurcas.htm (2020 June 3).

[22] Environmental Weeds of Australia for Biosecurity Queensland. Jatropha gossypiifolia L. 2016. https://keyserver.lucidcentral.org/weeds/data/ media/Html/jatropha-gossypiifolia.htm (2020 June 3)

[23] International Union for Conservation of Nature (IUCN). The IUCN Red List of Threatened Species (Version 2019-3). 2019. http:// www.iucnredlist.org (2020 January 24) 